\title{
Partisipasi Pengelola Gang Hijau dalam Mendukung Program Ruang Terbuka Hijau di Jakarta
}

\author{
Suryani ${ }^{1}$, Pudji Muljono ${ }^{2}$, Djoko Susanto ${ }^{2}$, dan Sri Harijati ${ }^{3}$ \\ ${ }^{1}$ Program Studi Agroteknologi Fakultas Pertanian Universitas Respati Indonesia \\ ${ }^{2}$ Departemen Sains Komunikasi dan Pengembangan Masyarakat Fakultas Ekologi Manusia IPB \\ ${ }^{3}$ Departemen Agribisnis Fakultas MIPA Universitas Terbuka \\ Email:edmaryani@yahoo.co.id
}

\begin{abstract}
Abstrak
Keberadaan Ruang Terbuka Hijau (RTH) sangat dibutuhkan masyarakat Jakarta. Menurunnya kualitas dan kuantitas RTH di wilayah perkotaan mengakibatkan kerusakan lingkungan hidup, peningkatan pencemaran udara, dan penurunan produktivitas masyarakat akibat terbatasnya ruang yang tersedia untuk interaksi sosial. Partisipasi masyarakat dalam penyediaan RTH sangat penting. Salah satu wujud RTH di Jakarta adalah adannya gang hijau. Penelitian bertujuan untuk mengkaji tingkat partisipasi masyarakat dalam pengelolaan gang hijau untuk mendukung program RTH. Penelitian ini menggunakan pendekatan kuantitatif dan kualitatif. Penelitian dilakukan di Provinsi DKI Jakarta, dengan waktu pengambilan data pada bulan Desember 2019 sampai dengan Februari 2020. Kecamatan dan Kelurahan dalam penelitian ini dipilih secara sengaja dengan kriteria wilayah tersebut melakukan usahatani pada gang hijau. Populasi penelitian sejumlah 2.236 responden, jumlah sampel ditentukan secara proporsional didapatkan 340 responden. Data dikumpulkan dengan menggunakan kuisioner, observasi, dan wawancara, serta studi dokumen. Analisis data menggunakan uji statistik deskriptif dan program Statistical Product and Service Solution (SPSS) versi 24 dan analisis statistik inferensial menggunakan program Partial Least Square (PLS) 3. Hasil penelitian menunjukkan bahwa partisipasi pengelola gang hijau di Jakarta dalam tahap perencanaan pada kategori rendah, kemudian pada tahap pelaksanaan, memanfaatkan hasil dan evaluasi berada pada kategori sedang.
\end{abstract}

Kata Kunci: partisipasi pengelola, gang hijau, ruang terbuka hijau

\section{PENDAHULUAN}

Perkembangan pembangunan kota akan mengakibatkan berkurangnya tingkat daya dukung lahan, sehingga menurunkan kualitas hidup dan produktivitas masyarakat [1. Pembangunan wilayah perkotaan yang tidak melalui perencanaan, peningkatan sosial ekonomi perkotaan diikuti dengan pertambahan jumlah penduduk, meluasnya penggunaan lahan untuk pemukiman dan ekonomi dari perkotaan hingga ke pinggiran kota, mengakibatkan berkurangnya Ruang Terbuka Hijau (RTH) dan lahan produktif pertanian di kota-kota besar Indonesia [2]. Kota-kota besar di Indonesia seperti Bandung, Yogyakarta dan Jakarta kuantitas dan kualitas RTH mengalami penurunan signifikan serta belum memenuhi proporsi RTH [3]. Amanat Undang-undang No. 26/2007 tentang Tata ruang proporsi minimal RTH sebesar 30 persen yang terdiri dari 20 persen RTH publik dan 10 persen RTH privat. Menurunnya RTH di wilayah perkotaan mengakibatkan kerusakan lingkungan hidup, peningkatan pencemaran udara, dan penurunan produktivitas masyarakat akibat terbatasnya ruang yang tersedia untuk interaksi sosial [4].

Daerah Khusus Ibukota Jakarta menjadi salah satu kota di Indonesia yang belum mencapai standar minimal proporsi RTH, sampai tahun 2019 ketersediaan RTH baru mencapai 14,9 persen dan terjadi penurunan luasan RTH sebesar 0,53 persen pada kurun waktu 2011 sampai dengan 2018 [5]. Keberadaan RTH sangat dibutuhkan masyarakat Jakarta untuk berolahraga, berinteraksi, meminimalkan terjadinya banjir, mengurangi polusi udara dan sumber bahan sayuran sehat

http://ejournal.urindo.ac.id/index.php/pertanian

Article History :

Sumbitted 11 Juni 2021, Accepted 30 Juni2021, Published 30 Juni2021 
dan segar. Salah satu wujud ketersediaan RTH di Jakarta adalah gang hijau. Gang hijau adalah sebuah gang atau jalur jalan kecil yang ditanami dengan berbagai jenis tanaman hortikultura yang diatur sedemikian rupa membentuk satu kesatuan manfaat dan estetika dalam suatu area pemukiman dan lahan sempit perkotaan [6]. Minimnya RTH di Jakarta mengganggu aspek ekonomi dan aspek sosial di masyarakat [7].

Ketersediaan RTH di Jakarta belum memenuhi standar yang di tetapkan oleh Undang-undang No. 26/2007 diduga terkait partisipasi masyarakat sebagai pengelola gang hijau yang masih rendah dalam memanfaatkan lahan pada gang-gang dipemukiman untuk ketersediaan RTH di Jakarta [8]. Partisipasi masyarakat dalam dalam pengelolaan gang hijau merupakan kunci bagi keberhasilan program RTH. Partisipasi adalah keterlibatan mental dan emosional individu dalam situasi kelompok yang mendorong untuk berkontribusi dalam usaha mencapai tujuan kelompok dan saling berbagi tanggung jawab pada setiap anggotanya [9]. Supaya masyarakat termotivasi untuk berpatisipasi perlu diperhatikan beberapa persyaratan antara lain; (1) masyarakat akan termotivasi berpartisipasi apabila kegiatan yang ditawarkan dianggap penting oleh mereka, (2) kegiatan yang ditawarkan dirasakan oleh masyarakat akan memberikan perbedaan yang nyata bagi kehidupannya, (3) partisipasi dari masyarakat harus dihargai dan diberi penghargaan yang tinggi, (4) adannya peluang bagi masyarakat untuk berpartisipasi, dan (5) struktur dan proses kegiatan bukan merupakan sesuatu yang asing bagi masyarakat [10].

Empat tahapan partisipasi, yaitu : ( 1$)$ partisipasi dalam perencanaan pembangunan yang termasuk di dalamnya pembuatan keputusan, ikut menyumbangkan gagasan atau pemikiran, kehadiran dalam rapat, diskusi, tanggapan atau penolakan terhadap program yang ditawarkan, (2) partisipasi dalam pelaksanaan yang meliputi menggerakan sumber daya dana, kegiatan administrasi, koordinasi dan penjabaran program, (3) partisipasi dalam memanfaatkan hasil yang mencakup partisipasi dalam menerima, memelihara, dan mengembangkan hasil pembangunan, dan (4) partisipasi dalam evaluasi partisipasi dalam melakukan penilaian terhadap pembangunan. Apabila partisipasi tidak melibatkan semua tahapan tersebut, maka dikatakan bahwa partisipasi hanya bersifat parsial, oleh karena itu partisipasi yang sesungguhnya harus terdiri keempat tahapan tersebut. Partisipasi evaluasi bertujuan untuk mengetahui ketercapaian program yang sudah direncanakan sebelumnya. Tahap evaluasi penting karena dianggap sebagai umpan balik yang dapat memberi masukkan demi perbaikan pelaksanaan program dan kegiatan selanjutnya [11].

Beberapa kendala terkait ketersediaan RTH dapat diatasi dengan upaya peningkatan partisipasi pengelola gang hijau. Berdasarkan latar belakang tersebut, maka tujuan penelitian ini adalah menemukan tingkat partisipasi pengelola gang hijau.

\section{METODE PENELITIAN}

Penelitian ini menggunakan pendekatan kuantitatif dan kualitatif. Penelitian dilakukan di Provinsi DKI Jakarta, dengan waktu pengambilan data pada bulan Desember 2019 sampai dengan Februari 2020. Kecamatan dan Kelurahan dalam penelitian ini dipilih secara sengaja dengan kriteria wilayah tersebut melakukan usahatani pada gang hijau. Populasi penelitian sejumlah 2.236 responden, jumlah sampel ditentukan secara proporsional didapatkan 340 responden. Jenis data yang dikumpulkan meliputi data primer dan data sekunder. Data primer dikumpulkan melalui wawancara dengan menggunakan kuesioner, wawancara mendalam, observasi dan studi dokumentasi. Sedangkan data sekunder dari hasil-hasil penelitian terdahulu, kajian pustaka yang relevan serta data yang dimiliki lembaga dan instansi terkait antara lain: Dinas Ketahanan Pangan, Kehutanan dan Pertanian (KPKP), Programa BPP dan penyuluh yang bertugas di wilayah lokasi penelitian. Analisis data menggunakan uji statistik deskriptif dan program Statistical Product and Service Solution (SPSS) versi 24 dan analisis statistik inferensial menggunakan program Partial Least Square (PLS) 3. Pengujian hipotesis satu arah dilakukan pada tingkat signifikansi dari nilai koefisien path yang ditunjukkan oleh nilai t-statistik harus di atas 1,96 untuk alpha 5 persen.

\section{HASIL DAN PEMBAHASAN}

Partisipasi merupakan bentuk keterlibatan langsung pengelola gang hijau 
dalam kegiatan pengelolaan gang hijau untuk mendukung program RTH. Partisipasi yang diamati dalam penelitian ini mencakup partisipasi dalam perencanaan, partisipasi dalam pelaksanaan, partisipasi dalam menikmati hasil dan partisipasi dalam evaluasi. Deskripsi lengkap mengenai partisipasi pengelola gang hijau dalam mendukung program RTH di Jakarta disajikan dalam Tabel 1. Tabel 1 Tingkat Partisipasi Pengelola Gang Hijau

\begin{tabular}{|c|c|c|c|c|}
\hline \multirow{2}{*}{ Tingkat Partisipasi } & \multirow{2}{*}{\multicolumn{2}{|c|}{ Kategori }} & \multicolumn{2}{|c|}{ Jumlah } \\
\hline & & & \multirow{2}{*}{$\begin{array}{c}\text { Orang } \\
45\end{array}$} & \multirow{2}{*}{$\begin{array}{r}\text { Persen } \\
13,2\end{array}$} \\
\hline Partisipasi dalam & Sangat rendah & (Skor 5-8) & & \\
\hline & Rendah & (Skor 9-12) & 129 & 37,9 \\
\hline & Sedang & (Skor 13-16) & 69 & 20,3 \\
\hline & Tinggi & (Skor 17-20) & 1 & 0,3 \\
\hline \multirow{4}{*}{$\begin{array}{l}\text { Partisipasi dalam } \\
\text { Pelaksanaan }\end{array}$} & Sangat rendah & (Skor 7-12) & 1 & 0,3 \\
\hline & Rendah & (Skor 13-17) & 40 & 11,8 \\
\hline & Sedang & (Skor 18-22) & 217 & 63,8 \\
\hline & Tinggi & (Skor 23-28) & 82 & 24,1 \\
\hline \multirow[t]{4}{*}{$\begin{array}{l}\text { Partisipasi dalam } \\
\text { Memanfaatkan Hasil }\end{array}$} & Sangat rendah & (Skor 5-8) & 3 & 0,9 \\
\hline & Rendah & (Skor 9-12) & 26 & 7,6 \\
\hline & Sedang & (Skor 13-16) & 159 & 46,8 \\
\hline & Tinggi & (Skor 17-20) & 152 & 44,7 \\
\hline \multirow[t]{4}{*}{$\begin{array}{l}\text { Partisipasi dalam } \\
\text { Evaluasi }\end{array}$} & Sangat Rendah & Skor 3-6) & 7 & 2,1 \\
\hline & Rendah & (Skor 7-8) & 77 & 22,6 \\
\hline & Sedang & (Skor 8-9) & 140 & 41,2 \\
\hline & Tinggi & (Skor 10-12) & 116 & 34,1 \\
\hline
\end{tabular}

Keterangan: $\mathrm{n}=340$

\section{Partisipasi Pengelola Gang Hijau dalam Perencanaan}

Perencanaan kegiatan pengelolaan RTH merupakan salah satu proses dalam pembangunan [5]. Partisipasi dalam perencanaan mencakup dalamnya pembuatan keputusan, ikut menyumbangkan gagasan atau pemikiran, kehadiran dalam rapat, diskusi, tanggapan atau penolakan terhadap program yang ditawarkan. Tingkat perencanaan pengelola gang hijau berada pada kategori rendah yaitu 37,9 persen. Hasil penelitian menunjukkan pengelola gang hijau kurang terlibat dalam penyusunan program, intensitas kehadiran dalam rapat rendah, sehingga setiap program yang di sosialisasikan kurang mereka pahami. Kemudian pengelola gang hijau yang hadir kurang aktif dalam memberikan gagasan untuk pengembangan gang hijau. Pada tahap perencanaan, setiap anggota KWT selalu hadir ketika ada rapat dengan penyuluh. Namun, kontribusi anggota dalam bertanya, memberikan pendapat dan mengambil keputusan pada rapat tersebut masih kurang [12]. Adannya kecenderungan yang selalu aktif bertanya dan menyampaikan ide adalah pengurus KWT.

Tidak terpenuhinya ketersediaan RTH di Jakarta sesuai ketentuan undang-undang karena kesadaran masyarakat tentang fungsi dan manfaat RTH masih kurang. Berdasarkan wawancara mendalam, diperoleh informasi bahwa pengelola gang hijau yang aktif merupakan masyarakat yang memang mempunyai hobby menanam, sedangkan yang lainnya hanya ikut-ikutan namun tidak konsisten [13]. Kesadaran masyarakat kelurahan Duren Jaya akan pentingnya menjaga RTH masih sangat kurang, akibat masih minimnya kepedulian masyarakat terhadap RTH dan ketidaktahuan mereka akan fungsi dan manfaat RTH. Hal ini dibuktikan masih banyak terdapat sampah disekitar area RTH di pemukiman, walaupun sudah diberi peringatan oleh Pemda, namun masyarakat masih banyak yang membuang sampah sembarangan [14]. 
Rendahnya partisipasi petani karena hutan rakyat belum dianggap sebagai kegiatan yang penting oleh petani karena tidak merubah hidup keluarganya tidak ada dukungan dari para pihak [15].

\section{Partisipasi dalam Pelaksanaan}

Partisipasi dalam pelaksanaan merupakan aktivitas pengelola gang hijau dalam mengelola gang hijau untuk RTH yang mencakup pengadaan benih tanaman tanaman, pembuatan bibit, penanaman, penyiraman, pemupukan, pengendalian hama penyakit, panen dan pengolahan pasca panen. Tingkat partisipasi dalam pelaksanaan pengelola gang hijau berada pada kategori sedang atau 63,8 persen. Maknanya, pengelola gang hijau sudah yang terlibat saat pembuatan bibit, penanaman menggunakan hidroponik, mengikuti saat panen dan pengolahan pasca panen. Pengelola gang hijau juga beranggapan bahwa kegiatan budidaya tanaman bukan merupakan sesuatu yang asing bagi mereka. Namun dalam pelaksanaanya tidak semua terlibat dalam penyiraman tanaman, pemupukan dan pengendalian OPT. Sehingga kegiatan tersebut dilakukan oleh pengurus kelompok atau tokoh masyarakat inisiator gang hijau saja yang rutin melakukan penyiraman tanaman pagi dan sore. Berdasarkan wawancara mendalam,diperoleh informasi, bahwa mereka tidak terlibat dalam kegiatan tersebut dengan alasan sibuk urusan pribadi, sehingga tidak sempat membantu menyiram tanaman. Hal ini mengindikasikan bahwa masih ada pengelola gang hijau yang kesadaran dan tanggung jawabnya rendah.

Pada tahap pelaksanaan, seluruh anggota KWT memang melakukan kegiatan pertanian perkotaan, namun tidak semua anggota terlibat dalam kegiatan memberikan nutrisi pada tanaman. Mereka berpendapat seharusnya orang yang melakukan pemberian nutrisi adalah yang paling paham ukuran nutrisi untuk tanaman hidroponik [12]. Dengan melibatkan masyarakat menjadi salah satu solusi untuk meningkatkan kesadaran masyarakat. Pemerintah Daerah DKI perlu melakukan sosialisasi pengembangan RTH yang dapat dilakukan di Jakarta melalui instansi pemerintah daerah yang secara resmi ditunjuk dan erat kaitannya dengan penghijauan kota, mulai dari tingkat kota, camat, lurah, hingga RW/RT lingkungan tempat tinggal [14].

Partisipasi dalam Memanfaatkan Hasil
Partisipasi pengelola gang hijau dalam memanfaatkan hasil adalah keterlibatan pengelola gang hijau dalam memanfaatkan gang hijau baik untuk tujuan komersial maupun untuk kebutuhan sendiri. Partisipasi dalam memanfaatkan hasil mencakup untuk variasi menu masakan keluarga, menjual hasil tanaman hias, tanaman sayuran dan tanaman obat keluarga. Tingkat partisipasi dalam pemanfataan hasil pengelola gang hijau berada pada kategori sedang yaitu 46,8 persen. Hal ini menunjukkan bahwa masyarakat sudah merasakan manfaat adannya gamg hijau dalam mendukung RTH. Pada umumnya pengelola gang hijau merasa mempunyai tanggung jawab untuk ikut menjaga lingkungan. Pemanfaatan hasil tanaman sayuran, tanaman obat keluarga dan tanaman hias sudah dirasakan oleh pengelola gang hijau, sehingga bisa menghemat pengeluaran keluarga dan dapat dialihkan untuk membeli kebutuhan hidup yang lain. Kenyataan ini menunjukan bahwa pengelola gang hijau teryakini akan manfaat tanaman sehat yang di tanam sendiri dilahan.

Berdasarkan wawancara mendalam, diperoleh informasi bahwa masyarakat yang memang senang bertani dan merasakan manfaat dari kegiatan pertanian di gang hijau. Sementara itu, masyarakat yang kontra menganggap pot-pot yang disusun secara vertikal dan diletakkan di gang yang sempit mengganggu aksesibilitas menuju rumah mereka. Oleh karena itu, perlu dilakukan edukasi kepada masyarakat akan pentingnya melakukan penanaman pada gang hijau, karena banyak manfaat yang diperoleh masyarakat, selain ekonomi dan estetika lingkungan, juga mendapatkan kenyamanan dalam menghirup udara segar. Jenis tanaman yang ditanam di setiap lokasi gang hijau ada yang sama dan ada juga yang berbeda. Pemerintah Provinsi DKI Jakarta merekomendasikan masyarakat menananm tanaman hortikulturta sesuai keunggulan wilayah masing-masing.

Pada tahap menikmati hasil, petani merasakan adanya tanaman hidroponik berupa lingkungan yang sehat dan indah. Kemudian, petani memperoleh keuntungan ekonomi dari adanya penjualan hasil panen hidroponik [12]. Penemuan tersebut diperkuat dengan penemuan bahwa walaupun kontribusinya kecil, namun pertanian di Jakarta masih bertahan dari kepunahan, karena 
bertransformasi dengan cara memperluas fungsi pertanian dari hanya fungsi tunggal sebagai penyedia pangan, khususnya pokok, menjadi multifungsi, seperti fungsi lingkungan, fungsi kultural dan fungsi penjaga klaim properti [16].

\section{Partisipasi dalam Evaluasi}

Partisipasi dalam evaluasi adalah keterlibatan pengelola gang hijau dalam kegiatan evaluasi terhadap pelaksanaan mencakup pemantauan program yang sudah dilaksanakan, memberikan penilaian terhadap hasil kegiatan dan memberi masukan pengembangan gang hijau untuk RTH kedepanya dalam hal pengadaan benih, bibit, penanaman, dan pengendalian hama penyakit dan panen. Tingkat partisipasi pengelola gang hijau dalam mengevaluasi program RTH berada pada kategori sedang yaitu 41,2 persen. Artinya bahwa pengelola gang hijau sudah memberikan penilaian terhadap program yang sudah selesai dilaksanakan dan memberikan ide pengembangan program yang akan datang pada saat rapat evaluasi program RTH. Namun demikian, pengelola gang hijau tidak memberikan kritik terhadap penentuan jenis tanaman dan hasil produksi yang di hasilkan. Berdasarkan wawancara mendalam, diperoleh informasi bahwa pengelola gang hijau menurut saja keputusan dari pengurus, mereka berpendapat penyuluh dan pengurus lebih berpengalaman dari dirinya. Kemudian untuk pengelola gang hijau mandiri menentukan sendiri tidak ketergantungan pihak lain.

Pada tahap evaluasi program, petani hadir dalam rapat evaluasi yang diadakan dengan penyuluh, namun dalam hal memberikan penilaian, saran, dan kritik dinilai masih kurang. Alasan anggota KWT tidak pernah memberikan kritik, karena mereka menganggap bahwa dirinya pun masih belajar tentang hidroponik dan belum mampu mengkritik tentang tanaman yang ada di KWT. Mereka beranggapan yang memberikan penilaian dan saran adalah orang-orang yang dianggap mengerti betul tentang perkembangan tanaman hidroponik [12].

\section{KESIMPULAN DAN SARAN}

\section{Kesimpulan}

Tingkat partisipasi pengelola gang hijau di Jakarta pada tahap perencanaan pada kategori rendah. Kemudian partisipasi pada tahap pelaksanaan, tahap memanfaatkan hasi dan tahap evaluasi pada kategori sedang.

Saran

Pemerintah Provinsi DKI Jakarta melalui Dinas Ketahanan Pangan, Kehutanan dan Pertanian perlu meningkatkan intensifikasi kegiatan penyuluhan untuk memberi motivasi dan sosialisasi kepada pengelola gang hijau untuk hadir dan aktif dalam rapat yang diselenggarakan oleh penyuluh. Dengan demikian, masyarakat akan termotivasi berpartisipasi dan menyadari bahwa kegiatan yang ditawarkan adalah penting untuk mereka dalam ketersediaan bahan makanan sehat, menghirup udara yang segar, meminimalkan terjadinya banjir di pemukiman.

Pemerintah Provinsi DKI Jakarta melalui Dinas Ketahanan Pangan, Kehutanan dan Pertanian perlu melibatkan masyarakat sebagai pengelola gang hijau dalam pembangunan RTH mulai dari perencanaan hingga evaluasi, sehingga ada rasa memiliki dan turut bertanggung jawab atas apa yang sudah dibangun.

\section{DAFTAR PUSTAKA}

Dominelli L 2012. Green Social Work: from Environmental Crises to Environmental Justice. Polity.

Surya, B, Syafri, S,Hadijah, H., Baharuddin, B. Fitriyah, A.T, Sakti, H.H.2020. Management of Slum-Based Urban Farming and Economic Empowerment of the Community of Makassar City, South Sulawesi, Indonesia. Sustainability, 12(18): 73-24.

Budiman A, Sulistyantara B, Zain AMF. 2014. Deteksi Perubahan Ruang Terbuka Hijau Pada 5 Kota Besar Di Pulau Jawa (Studi Kasus: DKI Jakarta, Kota Bandung, Kota Semarang, Kota Yogjakarta, dan Kota Surabaya. Jurnal Lanskap Indonesia. 6(1):115.

Permen PU No.05/ 2008. 2008. Peraturan Menteri Pekerjaan Umum. 2008. Pedoman Penyediaan dan Pemanfaatan Ruang Terbuka Hijau Di Kawasan Perkotaan.

Setiowati R. 2019. Pola Interaksi Para Pihak dalam Perumusan Masterplan Ruang Terbuka Hijau Di Provinsi DKI Jakarta.[Tesis]. Jakarta : Program Studi 
Lingkungan.

Indonesia. [diunduh

2020

Universitas

30].Tersedia

September pada

:https://www.academia.edu/38822888/.

Meidiantie D. 2019. Pengembangan Pertanian Perkotaan Di Jakarta. Agriculture World Summit (Tokyo). [Internet]. [diunduh 2020 Juli 25]. Tersedia pada www.city.nerima.tokyo.jp > uaws.files.

Sampeliling S, Sitorus S, Nurisyah S, Pramudya B. 2012. Kebijakan Pengembangan Pertanian Kota Berkelanjutan: Studi Kasus Di DKI Jakarta (Sustainable Urban Agriculture Development Policy: A Case Study In Jakarta). Jurnal Analisis Kebijakan Pertanian. (10) $3:$ 257-267.

UU RI N0.26/2007. Undang-Undang Republik Indonesia Nomor 26 Tahun 2007 tentang Penataan Ruang.

Davis K. 1967, Human Relations at Work: The Dynamic of Organization Behaviour. New York: McGraw-Hill Book Company.

Ife J. 1995. Community Development: Creating Community Alternatives - Vision,Anallysis and Practice: Australia: Longman Australia Pty. Ltd.

Kalesaran F, Rantung VV, Pioh NR. 2015. Partisipasi dalam Program Nasional Pemberdayaan Masyarakat Mandiri Perkotaan Kelurahan Taas Kota Manado. e-journal Acta Diurna. 4(5): 1-13.

Amaliyah N, Sarwoprasodjo S. 2018. Iklim Komunikasi Dan Partisipasi Dalam Program Pertanian Perkotaan.Jurnal Komunikasi Pembangunan.16 (1):1-14.
Cio M, Hamidah U, Triono A.2014. Pelaksanaan Pengaturan Penataan Ruang Terbuka Hijau dalam Rencana Tata Ruang Wilayah Provinsi DKI Jakarta. UNILA.Jurnal Ilmiah. 1(3):1-15.

Cahya DL, Widyawati LF, Ayodhia FK. 2016. Evaluasi ketersediaan ruang terbuka hijau di Kota Bekasi. Jurnal Planesa. 7(1):1-10.

Hudiyani I. 2013. Partisipasi Petani dalam Pengelolaan Hutan Rakyat di Desa Benteng Kabupaten Bogor Provinsi Jawa Barat. Jurnal Penyuluhan 9(2): 132-145.

Anggrahita H, Guswandi G. 2018. Keragaman Fungsi dan Bentuk Spasial Pertanian Kota (Studi Kasus: Pertanian Kota Di Jakarta). Jurnal wilayah dan lingkungan. 6 (3): 148163. 